\title{
PERSPECTIVE IN USING CHITOSAN FILMS FOR SENSORS
}

\author{
RALUCA MARIA AILENI, LAURA CHIRIAC, IRINA SANDULACHE \\ INCDTP, Lucretiu Patrascanu 16, Bucharest, Romania, e-mail: raluca.aileni@incdtp.ro
}

\begin{abstract}
This paper presents some aspects concerning the possibilities of using chitosan films for sensor development. The proposed approaches consist of the development of the experimental samples using $100 \%$ cotton fabrics (plain weave) coated with a conductive paste based on chitosan (low, medium, and high molecular weight) and copper microparticles. Our samples were obtained using the scraping method and free drying $(24 \mathrm{~h})$, followed by crosslinking $2-3$ minutes at $150-160^{\circ} \mathrm{C}$. Surface resistance was investigated using the resistance tester based on two parallel electrodes. The results showed that textile coated with chitosan paste with metallic particle content has a poorly conductive character. Based on the surface resistivity, was calculated the surface conductivity. Using the VCA Optima device was investigated the surface wettability by contact angle to conclude if the samples present a hydrophilic or hydrophobic character. After these tests, we concluded that almost all samples have a hydrophilic character due in large part to the fact that this polymer (chitosan) has hydrophilic nature.
\end{abstract}

Keywords: textile, chitosan, sensors

\section{INTRODUCTION}

The scientific interest in developing chitosan films for medicine due to the antimicrobial properties, sensors, food packaging, or heavy metals collecting, was increased because chitosan is a natural mucopolysaccharide of marine origin and is considered a friendly, biodegradable and biocompatible polymer. It is already known the antibacterial effect, heavy metal adsorption effect, antioxidation effect, and film development of the chitosan. Several studies on the mechanical properties of chitosan films reinforced with the cellulose of coconut fibers found that the tensile strength of the film was increased (Bhuvaneshwari et al., 2011).

Some scientific researches show the interest in using chitosan film for the acetonebased gas sensor in order to detect acetone concentrations in human breath in case of the diagnosis of diabetes mellitus in patients (Nasution et al., 2013) or to detect heavy metals from water (Sugunan et al., 2005; Ahmed and Fekry, 2013).

However, chitosan blended with polyethylene oxide (PEO) showed lower water vapor permeability values than chitosan/poly (N-vinyl-2-pyrrolidone) (PVP) films (Li, 2008). In the case of the chitosan, films were prepared by casting method, and neutralization treatment with sodium hydroxide $(10 \% \mathrm{NaOH})$ solution was observed that the increasing in mechanical property and a reduction in swelling property, water vapor permeability, and oxygen permeability is a directly proportional relationship with the $\mathrm{NaOH}$ concentration increasing (Chang et al., 2019). A flexible chitosan film developed using lactic acid solutions as solvent was reported with an increased wettability directly depending on the lactic acid ratio used (Niamsa and Baimark, 2009).

Also, some scientific papers show the concerns in the development of the multifunctional nanocomposites of chitosan with silver nanoparticles, copper nanoparticles, and carbon nanotubes because of increased antimicrobial activity, in approximatively 10 minutes, against bacteria such as Gram-negative and Gram-positive bacteria, E. coli, Staphylococcus aureus (Morsi et al., 2017; Haldorai and Shim, 2013). Chitosan (CS) based copper oxide $(\mathrm{CuO})$ hybrid material has reported a material with high photocatalytic activity and antibacterial activity against Escherichia coli (Haldorai and Shim, 2013). 


\section{EXPERIMENTAL PART}

In our experimental part, 12 samples from $100 \%$ cotton (plain weave) were coated with thin films based 1-2\% chitosan with low (chitosan 1), medium (chitosan 2) and high molecular (chitosan 3) weight and copper microparticles (size dimension 14-25 $\mu \mathrm{m})$, being followed by drying for 24 hours at room temperature and crosslinking at $150-160^{\circ} \mathrm{C}$ for $3-5$ minutes (Table 1). In order to obtain the paste, the chitosan powder was dissolved in a $0.5-2 \%$ acetic acid solution. The chitosan film was deposited by the scraping method. In Table 1, the surface resistance was measured before $\left(\mathrm{Rs}_{1}\right)$ and after $\left(\mathrm{Rs}_{2}\right)$ crosslinking. Besides, the electroconductive behavior was appreciated before (electroconductive effect ${ }_{1}$ ) and after (electroconductive effect ${ }_{2}$ ) crosslinking. The wettability of fabric coated was investigated through contact angles for the 12 samples developed were measured by using the device VCA Optima (AST - Figure 1) and is presented in Table 2. In Figure 2 are presented images showing the canvas - surface morphology before and after chitosan-copper pasta deposition for sample no. 2.

Table 1. Electrical characterization of the experimental samples functionalized by chitosan and $\mathrm{Cu}$ microparticles

\begin{tabular}{|c|c|c|c|c|c|c|c|c|c|c|}
\hline$\dot{0}$ & 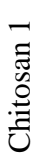 & 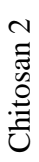 & 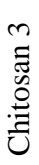 & 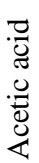 & $\begin{array}{l}\underset{N}{I} \\
\underset{I}{1}\end{array}$ & $=$ & $\begin{array}{l}\overrightarrow{\mathrm{c}} \\
\bar{a}\end{array}$ & 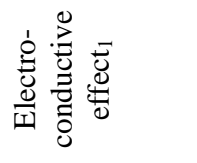 & $\frac{\overrightarrow{\underline{a}}}{\tilde{\mathscr{a}}}$ & 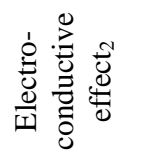 \\
\hline 1 & $\mathrm{X}$ & & & $\mathrm{X}$ & $\mathrm{X}$ & $\mathrm{X}$ & $10^{9}$ & antistatic & $10^{12}$ & antistatic \\
\hline 2 & $\mathrm{x}$ & & & $\mathrm{x}$ & $\mathrm{x}$ & $\mathrm{x}$ & $10^{3}$ & conductive & $10^{4}$ & conductive \\
\hline 3 & $\mathrm{x}$ & & & $\mathrm{x}$ & $\mathrm{x}$ & $\mathrm{x}$ & $10^{4}$ & conductive & $10^{4}$ & conductive \\
\hline 4 & & & $\mathrm{x}$ & $\mathrm{x}$ & $\mathrm{x}$ & $\mathrm{x}$ & $10^{7}$ & semiconductor & $10^{9}$ & antistatic \\
\hline 5 & & $\mathrm{X}$ & & $\mathrm{x}$ & $\mathrm{x}$ & $\mathrm{x}$ & $10^{4}$ & conductive & $10^{10}$ & antistatic \\
\hline 6 & $\mathrm{X}$ & & & $\mathrm{X}$ & $\mathrm{X}$ & $\mathrm{X}$ & $10^{7}$ & semiconductor & $10^{9}$ & antistatic \\
\hline 7 & & & $\mathrm{x}$ & $\mathrm{x}$ & $\mathrm{x}$ & $\mathrm{X}$ & $10^{8}$ & antistatic & $10^{11}$ & antistatic \\
\hline 8 & & & $\mathrm{x}$ & $\mathrm{x}$ & $\mathrm{x}$ & $\mathrm{X}$ & $10^{4}$ & conductive & $10^{11}$ & antistatic \\
\hline 9 & & & $\mathrm{x}$ & $\mathrm{x}$ & $\mathrm{x}$ & $\mathrm{x}$ & $10^{10}$ & antistatic & $10^{11}$ & antistatic \\
\hline 10 & & $\mathrm{X}$ & & $\mathrm{x}$ & $\mathrm{x}$ & $\mathrm{x}$ & $10^{11}$ & antistatic & $10^{12}$ & antistatic \\
\hline 11 & & $\mathrm{x}$ & & $\mathrm{x}$ & $\mathrm{x}$ & $\mathrm{x}$ & $10^{7}$ & semiconductor & $10^{12}$ & antistatic \\
\hline 12 & & $\mathrm{x}$ & & $\mathrm{x}$ & $\mathrm{x}$ & $\mathrm{x}$ & $10^{6}$ & semiconductor & $10^{12}$ & antistatic \\
\hline
\end{tabular}

Table 2. Contact angles - VCA Optima

\begin{tabular}{|c|c|c|c|}
\hline No. & $\begin{array}{l}\text { View - Textile material after Chitosan - } \\
\text { Cu film deposition }\end{array}$ & $\begin{array}{c}\text { Contact } \\
\text { angle }\left[{ }^{0}\right]\end{array}$ & $\begin{array}{c}\text { Hydrophobic/hydrophilic } \\
\text { character }\end{array}$ \\
\hline 1 & aiti2 & 0 & Hydrophilic \\
\hline
\end{tabular}

https://doi.org/10.24264/icams-2020.I.1 


\begin{tabular}{|c|c|c|c|}
\hline No. & $\begin{array}{c}\text { View - Textile material after Chitosan - } \\
\text { Cu film deposition }\end{array}$ & $\begin{array}{c}\text { Contact } \\
\text { angle }\left[{ }^{0}\right]\end{array}$ & $\begin{array}{c}\text { Hydrophobic/hydrophilic } \\
\text { character }\end{array}$ \\
\hline 2 & 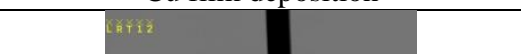 & 0 & Hydrophilic \\
\hline 3 & & 46.90 & Hydrophilic \\
\hline 4 & & 43.50 & Hydrophilic \\
\hline 5 & & 107.40 & Hydrophobic \\
\hline 6 & iz & 0 & Hydrophilic \\
\hline 7 & $\overline{1 i 2}$ & 0 & Hydrophilic \\
\hline 8 & fì & 0 & Hydrophilic \\
\hline 9 & $\sqrt{12}$ & 0 & Hydrophilic \\
\hline
\end{tabular}

https://doi.org/10.24264/icams-2020.I.1 
Perspective in Using Chitosan Films for Sensors

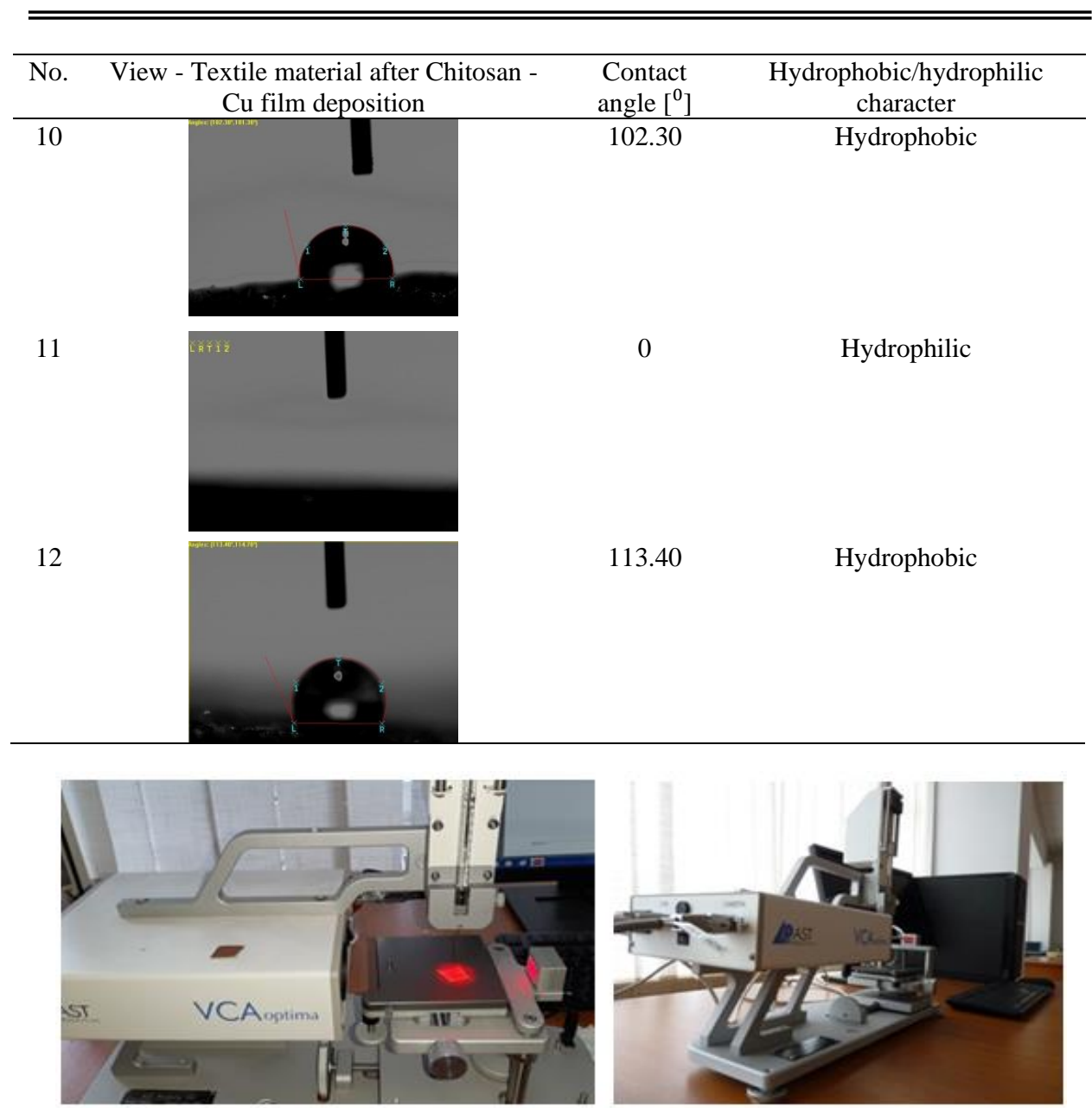

Figure 1. VCA Optima device

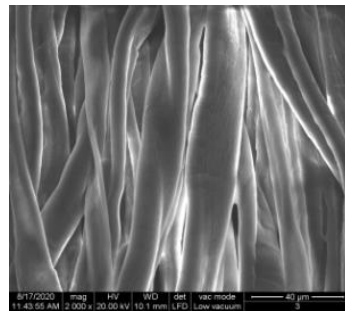

a. Sample 2 - raw fabric (magnitude 2000X)

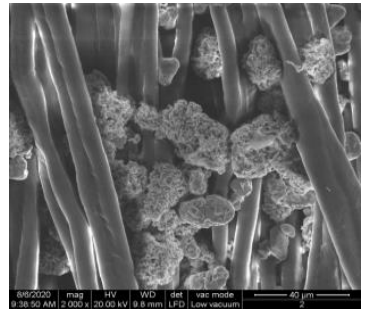

b. Sample 2 coated (magnitude 2000X)

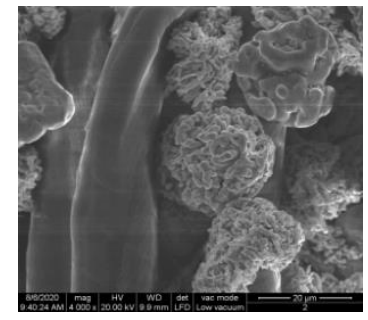

c. Sample 2 coated (magnitude 4000X)

Figure 2. SEM images showing the canvas - surface morphology before and after chitosan-copper paste deposition 


\section{DISCUSSIONS}

Following the wettability test using the VCA Optima device, we can appreciate that for samples 5, 9, and 12, the values of the contact angles are in the range [102.3113.40], but after 60 seconds, the distilled water drop $(4 \mu \mathrm{l})$ is absorbed, and the textile material sample is restored to initial condition.

From Table 1, it is evident that from the initial conductive samples $(2,3,5$, and 8$)$, after the crosslinking only samples 2 and 3 are still conductive. In the case of the samples, 2 and 3 were observed minor changes in the surface resistance, such as: for sample 2 , the surface resistance was increased with $1 \%$, respective for sample 3 , the surface resistance was not changed. After crosslinking, samples 5 and 8 become antistatic, and the surface resistances were increased with $150 \%$ for sample 5, respective with $175 \%$ for sample 8 .

Besides, it was investigated the correlation between contact angle and values of the surface resistance and because of the correlation coefficient $R_{\text {Resistance, Contact angle }}$ is 0.2756 . This means that between the contact angle values and the surface resistance (1), it is a low correlation.

$R_{\text {Resistance, Contact angle }}=\left|\begin{array}{ll}1.0000 & 0.2756 \\ 0.2756 & 1.0000\end{array}\right|$

Overall, the other samples after free drying or crosslinking become antistatic by increasing the surface resistance with $1 \%-100 \%$.

\section{CONCLUSIONS}

We can conclude that samples 2 and 3 obtained by chitosan low molecular weight and copper microparticles have the potential to be used in sensors application because they are conductive before and after crosslinking.

The surface resistance is not dependent on the wetting capacity of the fabric, and crosslinking involving a supplementary drying generates moisture loss and leads to increasing the surface resistance and decreasing the conductivity.

\section{REFERENCES}

Ahmed, R.A. and Fekry, A.M. (2013), "Preparation and characterization of a nanoparticles modified chitosan sensor and its application for the determination of heavy metals from different aqueous media", Int $J$ Electrochem Sci, 8(3), 6692-6708.

Bhuvaneshwari, S., Sruthi, D., Sivasubramanian, V., Niranjana, K. and Sugunabai, J. (2011), "Development and characterization of chitosan films", International Journal of Engineering Research and Applications, 1(2), 292-299.

Chang, W., Liu, F., Sharif, H.R., Huang, Z., Goff, H.D. and Zhong, F. (2019), "Preparation of chitosan films by neutralization for improving their preservation effects on chilled meat", Food Hydrocolloids, 90, 5061, https://doi.org/10.1016/j.foodhyd.2018.09.026.

Haldorai, Y. and Shim, J.J. (2013), "Multifunctional chitosan-copper oxide hybrid material: photocatalytic and antibacterial activities", International Journal of Photoenergy, https://doi.org/10.1155/2013/245646.

$\mathrm{Li}, \mathrm{J}$. (2008), "Characterization and performance improvement of chitosan films as affected by preparation method, synthetic polymers, and blend ratios", $\mathrm{PhD}$ diss., University of Tennessee, https://trace.tennessee.edu/utk_graddiss/464.

Morsi, R.E., Alsabagh, A.M., Nasr, S.A. and Zaki, M.M. (2017), "Multifunctional nanocomposites of chitosan, silver nanoparticles, copper nanoparticles and carbon nanotubes for water treatment: antimicrobial characteristics", International Journal of Biological Macromolecules, 97, 264-269, https://doi.org/10.1016/j.ijbiomac.2017.01.032.

https://doi.org/10.24264/icams-2020.I.1 


\section{Perspective in Using Chitosan Films for Sensors}

Nasution, T.I., Nainggolan, I., Hutagalung, S.D., Ahmad, K.R. and Ahmad, Z.A. (2013), "The sensing mechanism and detection of low concentration acetone using chitosan-based sensors", Sensors and Actuators B: Chemical, 177, 522-528, https://doi.org/10.1016/j.snb.2012.11.063.

Niamsa, N. and Baimark, Y. (2009), "Preparation and characterization of highly flexible chitosan films for use as food packaging", American Journal of Food Technology, 4(4), 162-169, https://doi.org/10.3923/ajft.2009.162.169.

Sugunan, A., Thanachayanont, C., Dutta, J. and Hilborn, J.G. (2005), "Heavy-metal ion sensors using chitosan-capped gold nanoparticles", Science and Technology of Advanced Materials, 6(3-4), 335, https://doi.org/10.1016/j.stam.2005.03.007. 